\title{
Analysis of Mathematics Teacher Performance in Building Resilience and Mathematical Literacy on Student Learning Outcomes
}

\author{
Hardi Tambunan \\ Department of Mathematics Education, Nommensen HKBP University, Medan, Indonesia \\ Received October 27, 2020; Revised December 14, 2020; Accepted January 20, 2021
}

\section{Cite This Paper in the following Citation Styles}

(a): [1] Hardi Tambunan, "Analysis of Mathematics Teacher Performance in Building Resilience and Mathematical Literacy on Student Learning Outcomes," Universal Journal of Educational Research, Vol. 9, No. 1, pp. 108 - 115, 2021. DOI: 10.13189/ujer.2021.090112.

(b): Hardi Tambunan (2021). Analysis of Mathematics Teacher Performance in Building Resilience and Mathematical Literacy on Student Learning Outcomes. Universal Journal of Educational Research, 9(1), 108 - 115. DOI: 10.13189/ujer.2021.090112.

Copyright $\bigcirc 2021$ by authors, all rights reserved. Authors agree that this article remains permanently open access under the terms of the Creative Commons Attribution License 4.0 International License

\begin{abstract}
The purpose of this study was to determine the performance of mathematics teachers in building resilience and mathematical literacy towards student learning outcomes. This type of research is ex post facto with a sample of 283 students from a population of 961 students consisting of seven states and five private high schools, and obtained in clusters from twelve sub-districts in North Sumatra. The research instrument used a questionnaire and test. The data analysis used descriptive and inferential analysis. The results of the descriptive analysis conclude several things, namely (1) the teacher's performance in building mathematical resilience and literacy is in the medium category, (2) students' mathematical resilience, students' mathematical literacy abilities, and student learning outcomes are in the medium category. The results of inferential analysis show that the teacher's performance in building mathematical resilience, (1) has a high impact on the mathematical resilience of students which is influenced by students' mathematical literacy abilities to influence student learning outcomes, and (2) has a high impact on students' mathematical literacy abilities which is influenced by students' mathematical resilience to affect student learning outcomes. The teacher's performance in building mathematical literacy, (3) has a high impact on students' mathematical resilience which is influenced by students' mathematical literacy abilities to influence student learning outcomes, and (4) has a high impact on students' mathematical literacy abilities which is influenced by students'
\end{abstract}

mathematical resilience to influence student learning outcomes in math. Thus it can be stated that the performance of teachers in building resilience and mathematical literacy has an impact on student learning outcomes.

Keywords Performance, Building, Resilience, Literacy, Learning Outcomes

\section{Introduction}

Mathematics is studied in schools from basic education to higher education in Indonesia. The purpose of mathematics education is to develop problem-solving abilities, build students' reasoning and creativity as a basis for following developments in science and technological knowledge, and apply them in everyday life. How are the learning outcomes of Indonesian students in mathematics? The Programme for International Student Assessment (PISA) report in 2018 [1] shows that student learning outcomes have not matched expectations, because the mathematics education score is ranked 73 out of 78 countries. The focus of the observed ability to determine the ranking is based on the students' mathematical literacy abilities. Mathematical literacy is the individual's ability to formulate, apply and interpret mathematics in various contexts, including the ability to do mathematical 
reasoning [2]. Mathematical literacy is the ability to apply mathematics in everyday life [3-4]. Mathematical literacy is the ability of individuals to formulate, apply and interpret mathematics in various contexts [5]. Thus, improving mathematical literacy skills will simultaneously improve student learning outcomes and the quality of education in Indonesia [6].

Many factors can affect learning outcomes, both internal and external factors. Internal factor is students' perceptions of mathematics. The results of the study show that perception is related to students' ability to learn mathematics [7]. Students' perceptions of mathematics can affect mathematics achievement [8]. There are differences in achievement between students who have positive perceptions and students who have negative perceptions of mathematics [9]. Positive perceptions of mathematics greatly influence mathematics learning outcomes [10]. A positive attitude towards mathematics education is called mathematical resilience [11]. Dweck [12] stated that mathematical resilience is a persistent attitude in facing difficulties in understanding mathematics. Resilience in mathematics is an ability that allows students to face difficult situations, which can have a negative impact [13]. Academic resilience is the ability of students to cope with, respond to, and handle difficulties in doing assignments [14-15], and resilience is related to individual success [16].

Mathematical resilience is an important internal factor in mathematics education [17]. The characteristics of a person having resilience are persistence, hard work, and focus on goals [18]. When viewed from external factors, teachers play an important role in influencing student learning outcomes [19]. The teacher acts as an informator and organizer in the implementation of learning [20]. Thus, the failure of students in learning mathematics in terms of teacher factors can be caused by poor implementation of the learning process, or [21] the interaction of teaching methods is not good [22].

Based on the above description, the learning outcomes of Indonesian students in mathematics are not good in terms of ranking, compared to other countries [1]. This shows that there is a problem in learning mathematics. This problem can be caused by mathematical resilience factors and mathematical literacy abilities. The results of the study indicate that there is an effect of mathematical resilience ability on student learning outcomes [23]. Meanwhile, the impact of mathematical literacy skills is positively related to student achievement [24-25]. Seeing the role of resilience and mathematical literacy in student mathematics achievement, the teacher is very instrumental in building these two factors. Teachers have a role to develop resilience [26], and improve students' mathematical literacy [7]. So the research questions are;

1. How does the teacher's performance build resilience and mathematical literacy, and student learning outcomes?
2. What is the impact of teacher performance, mathematical resilience and mathematical literacy skills on student learning outcomes?

This study aims to determine the performance of teachers in building resilience and mathematical literacy, and their impact on student learning outcomes in mathematics. The results obtained can be useful as a basis for overcoming problems with student learning outcomes through teacher performance, resilience and mathematical literacy, in order to obtain better mathematics education outcomes.

\section{Materials and Methods}

\subsection{Research Type and Research Variable}

This type of research is ex post facto, because this study reveals past events [27]. The variables of this study consist of independent and dependent variables. The independent variable consists of the teacher's performance in building resilience $\left(\mathrm{X}_{1}\right)$ and building literacy $\left(\mathrm{X}_{2}\right)$, students' mathematical resilience $\left(\mathrm{Y}_{1}\right)$ and students' mathematical literacy abilities $\left(\mathrm{Y}_{2}\right)$. The dependent variable is student learning outcomes in mathematics $(\mathrm{Z})$.

\subsection{Research Design}

The research design is stated as the path diagram in Figure 1 below.

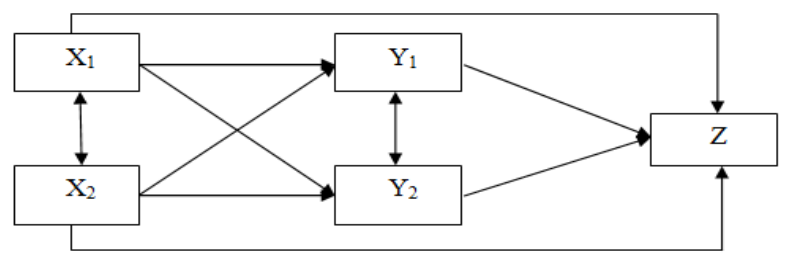

Figure 1. Path Diagram

\subsection{Population and Sample}

The study population was 961 students from seven states and five private high schools, which were drawn as clusters from twelve sub-districts in North Sumatra. The sampling technique uses the Slovin formula [28], = $\frac{N}{1+N e^{2}}$, where $N$ : total population, and $e=0.05$. Based on the results of the calculation, the total sample size was 283 students.

\subsection{Research Instrument}

The data collection instruments were questionnaires and liteation questions. The questionnaire consists of two parts, namely a questionnaire to measure teacher performance, and students' mathematical resilience. The questionnaire contains six indicators, namely (1) persistence in learning 
mathematics, (2) self-confidence, (3) studying hard, (4) overcoming anxiety, (5) overcoming difficulties, and (6) attitude towards facing difficulties in learning mathematics. The questions to test mathematical literacy skills contain 3 ability items, namely (1) formulating, (2) interpreting, and (3) applying mathematics to various contexts, and achievement scores are obtained from school documents. Test the reliability of the questionnaire and questions using the Cronbach's Alpha formula [29], that is $\alpha=\left[\frac{N}{N-1}\right]\left[\frac{\sigma_{x-\Sigma_{i=1}^{N} \sigma_{y_{i}}^{2}}^{2}}{\sigma_{x}^{2}}\right]$, reliable instrument criteria if $\alpha \geq 0.707$. Based on calculations using SPSS version 21, Cronbach's Alpha values were 0.725, 0.804, 0.724, and 0.808 respectively for the teacher performance questionnaire instrument to build mathematical resilience, mathematical literacy, and a questionnaire to measure resilience and mathematical literacy questions. This means that the questionnaire and questions are reliable.

\subsection{Data Collection Technique}

The research data collection technique was carried out by giving questionnaires and mathematical literacy questions to students as respondents. Questionnaires cover the performance of mathematics teachers in building mathematical resilience and literacy, and questionnaires to determine the size of students' resilience to mathematics. To measure mathematical literacy skills, students are given questions in the form of mathematical problems. Furthermore, the cognitive aspects of student learning outcomes were obtained from school documents, namely the final grade of the semester.

\subsection{Data Analysis Techniques}

Data analysis used descriptive and inferential analysis. Descriptive analysis was used to determine the categories of teacher performance, resilience and mathematical literacy skills, and student learning outcomes. Descriptive analysis was used to determine the category of each research variable, then the mean $(M)$ and standard deviation $(S D)$ were used to obtain an interpretation of the intervals and categories [27] as stated in Table 1 below.

Table 1. Data Intervals and Categories

\begin{tabular}{|c|c|}
\hline Intervals & Categories \\
\hline $\mathrm{X}>M+\mathrm{SD}_{\mathrm{i}}$ & High \\
$M-\mathrm{SD}_{\mathrm{i}}<\mathrm{X} \leq M+\mathrm{SD}_{\mathrm{i}}$ & Medium \\
$\mathrm{X}<M-\mathrm{SD}_{\mathrm{i}}$ & Low \\
\hline
\end{tabular}

Inferential analysis is used to determine the correlation coefficient and whether there is an influence between the two variables. Path analysis is used to determine the simultaneous relationship between exogenous variables and endogenous variables [30]. The analysis was carried out in three stages, namely (1) testing the significance of correlation between variables, (2) calculating the magnitude of the path coefficient, and (3) calculating the path coefficient from exogenous variables to endogenous variables. Meanwhile, to determine the impact of the pathway, the path coefficient interpretation of the research variables was used based on the correlation coefficient [27] as stated in Table 2 below.

Table 2. Interpretation of the correlation coefficient

\begin{tabular}{|c|c|}
\hline Correlation Coefficient & Impact \\
\hline $0.81-1.00$ & Very high \\
$0.61-0.80$ & High \\
$0.41-0.60$ & Moderate \\
$0.21-0.40$ & Low \\
$0.00-0.20$ & Very low \\
\hline
\end{tabular}

\section{Results}

\subsection{Result of Descriptive Analysis}

The results of data analysis using SPSS version 21 software, descriptive statistical values are stated in Table 3 below.

Table 3. Descriptive Statistics

\begin{tabular}{|c|c|c|c|c|c|}
\hline Variable & $\mathrm{N}$ & Minimum & Maximum & Mean & Std. Deviation \\
\hline $\mathrm{X}_{1}$ & 283 & 50.00 & 75.00 & 62.6201 & 4.42988 \\
\hline $\mathrm{X}_{2}$ & 283 & 50.00 & 75.00 & 62.6131 & 4.41242 \\
\hline $\mathrm{Y}_{1}$ & 283 & 50.00 & 75.00 & 62.5583 & 4.83277 \\
\hline $\mathrm{Y}_{2}$ & 283 & 45.00 & 77.00 & 62.6961 & 5.52970 \\
\hline $\mathrm{Z}$ & 283 & 50.00 & 78.00 & 63.8304 & 5.56262 \\
\hline Valid N & 283 & & & & \\
\hline
\end{tabular}

$\mathrm{X}_{1}$ : Teacher performance builds resilience.

$\mathrm{X}_{2}$ : Teacher performance builds literacy

$\mathrm{Y}_{1}$ : Student mathematical resilience.

$\mathrm{Y}_{2}$ : Student mathematical literacy.

$\mathrm{Z}$ : Learning outcomes

Based on Table 1 and the data in Table 3, the categories of variables $\mathrm{X}_{1}, \mathrm{X}_{2}, \mathrm{Y}_{1}, \mathrm{Y}_{2}$ and $\mathrm{Z}$ are stated in Table 4 below.

Table 4. Frequency Distribution and Categories

\begin{tabular}{|c|c|c|c|c|}
\hline Variable & Interval & $\mathrm{f}$ & $\%$ & Categories \\
\hline & $\mathrm{I}_{1}>67$ & 32 & 11.30 & High \\
$\mathrm{X}_{1}$ & $58 \leq \mathrm{I}_{2} \leq 67$ & 225 & 79.51 & Medium \\
& $\mathrm{I}_{3}<58$ & 26 & 9.19 & Low \\
\hline & $\mathrm{I}_{1}>67$ & 30 & 10.60 & High \\
$\mathrm{X}_{2}$ & $58 \leq \mathrm{I}_{2} \leq 67$ & 226 & 79,86 & Medium \\
& $\mathrm{I}_{3}<58$ & 27 & 9,54 & Low \\
\hline \multirow{3}{*}{$\mathrm{Y}_{1}$} & $\mathrm{I}_{1}>67$ & 27 & 9.54 & High \\
& $57 \leq \mathrm{I}_{2} \leq 67$ & 226 & 79.86 & Medium \\
& $\mathrm{I}_{3}<57$ & 30 & 10.60 & Low \\
\hline & $\mathrm{I}_{1}>68$ & 44 & 15.55 & High \\
$\mathrm{Y}_{2}$ & $57 \leq \mathrm{I}_{2} \leq 68$ & 199 & 70.32 & Medium \\
& $\mathrm{I}_{3}<57$ & 40 & 14.13 & Low \\
\hline \multirow{3}{*}{$\mathrm{Z}$} & $\mathrm{I}_{1}>69$ & 58 & 20.49 & High \\
& $58 \leq \mathrm{I}_{2} \leq 69$ & 187 & 66.08 & Medium \\
& $\mathrm{I}_{3}<58$ & 38 & 13.43 & Low \\
\hline
\end{tabular}


Based on Table 3 and Table 4, it can be described that the mean for all variables, namely variables $\mathrm{X}_{1}, \mathrm{X}_{2}, \mathrm{Y}_{1}$, $\mathrm{Y}_{2}$ and $\mathrm{Z}$ is in the second interval $\left(\mathrm{I}_{2}\right)$ in the medium category. This shows that the teacher's performance builds mathematical resilience and students' mathematical literacy is in the medium category. Mathematical resilience, mathematical literacy skills and student learning outcomes in mathematics are in the medium category.

\subsection{Result of Inferential Analysis}

The results of data analysis using SPSS version 21 software obtained the correlation coefficient between the two variables with the $r$ test. Summary of the correlation analysis is as in Table 5 below.

Table 5. Correlations

\begin{tabular}{|c|c|c|c|c|c|c|}
\hline \multicolumn{2}{|c|}{} & $\mathrm{X}_{1}$ & $\mathrm{X}_{2}$ & $\mathrm{Y}_{1}$ & $\mathrm{Y}_{2}$ & $\mathrm{Z}$ \\
\hline \multirow{4}{*}{$\mathrm{X}_{1}$} & Pearson Correlation & 1 & $.974^{* *}$ & $.652^{* *}$ & $.638^{* *}$ & $.576^{* *}$ \\
\cline { 2 - 7 } & Sig. (2-tailed) & & .000 & .000 & .000 & .000 \\
\cline { 2 - 7 } & $\mathrm{N}$ & 283 & 283 & 283 & 283 & 283 \\
\hline \multirow{4}{*}{$\mathrm{X}_{2}$} & Pearson Correlation & $.974^{* *}$ & 1 & $.647^{* *}$ & $.626^{* *}$ & $.560^{* *}$ \\
\cline { 2 - 7 } & Sig. (2-tailed) & .000 & & .000 & .000 & .000 \\
\cline { 2 - 7 } $\mathrm{Y}_{1}$ & $\mathrm{~N}$ & 283 & 283 & 283 & 283 & 283 \\
\cline { 2 - 7 } & Pearson Correlation & $.652^{* *}$ & $.647^{* *}$ & 1 & $.672^{* *}$ & $.661^{* *}$ \\
\cline { 2 - 7 } & Sig. (2-tailed) & .000 & .000 & & .000 & .000 \\
\hline \multirow{4}{*}{$\mathrm{Y}_{2}$} & N & 283 & 283 & 283 & 283 & 283 \\
\cline { 2 - 7 } & Pearson Correlation & $.638^{* *}$ & $.626^{* *}$ & $.672^{* *}$ & 1 & $.615^{* *}$ \\
\cline { 2 - 7 } & Sig. (2-tailed) & .000 & .000 & .000 & & .000 \\
\hline \multirow{3}{*}{$\mathrm{Z}$} & N & 283 & 283 & 283 & 283 & 283 \\
\cline { 2 - 7 } & Pearson Correlation & $.576^{* *}$ & $.560^{* *}$ & $.661^{* *}$ & $.615^{* *}$ & 1 \\
\cline { 2 - 7 } & Sig. (2-tailed) & .000 & .000 & .000 & .000 & \\
\hline \multirow{2}{*}{ N N . Correlation is significant at the 0.01 level (2-tailed). } & 283 \\
\hline \multirow{7}{*}{} & 283 & 283 & 283 & 283 & 283 \\
\hline
\end{tabular}

Based on Table 5, it can be stated that all variables have a very significant correlation. This means that all exogenous variables have a significant pathway to endogenous variables. The path can be expressed as Figure 2 below.

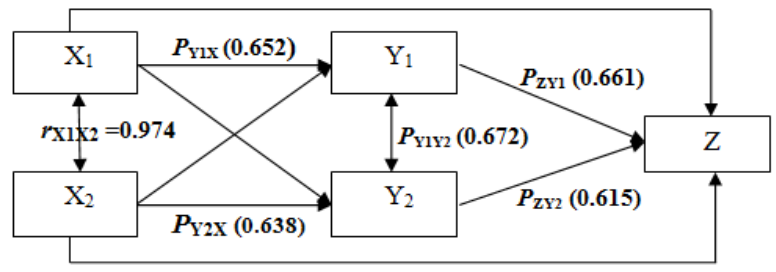

Figure 2. Path diagram and correlation

Based on Figure 2, a path equation can be made, namely direct and correlational paths. The path equation from $\mathrm{X}_{1}$ to $Z$, namely (1) $\mathrm{P}_{1}: \boldsymbol{r}_{\boldsymbol{X} \mathbf{Z}}=\boldsymbol{p}_{\boldsymbol{Z} \boldsymbol{X} \mathbf{1}}$, (2) the path equation through $\mathrm{Y}_{1}$, namely $\mathrm{P}_{2}: \boldsymbol{r}_{\boldsymbol{X} \mathbf{Z}}=\boldsymbol{p}_{\boldsymbol{Y} \mathbf{1 X 1}} \boldsymbol{r}_{\boldsymbol{X} \mathbf{1 Y 1}}+$ $\boldsymbol{p}_{Z Y 1} \boldsymbol{r}_{Y 1 Z}$, and (3) the path equation through $\mathrm{Y}_{2}$, namely $\mathrm{P}_{3}: \boldsymbol{r}_{X 1 Z}=\boldsymbol{p}_{Y 2 X 1} \boldsymbol{r}_{X 1 Y 2}+\boldsymbol{p}_{Z Y 2} \boldsymbol{r}_{Y 2 Z}$. The path equation from $\mathrm{X}_{2}$ to $\mathrm{Z}$, namely (4) direct path, namely $\mathrm{P}_{4}$ : $\boldsymbol{r}_{X 2 Z}=\boldsymbol{p}_{Z X 2}$, (5) the path equation through $\mathrm{Y}_{1}$, namely $\mathrm{P}_{5}: \quad \boldsymbol{r}_{X 2 Z}=\boldsymbol{p}_{Y 1 X 2} \boldsymbol{r}_{X 2 Y 1}+\boldsymbol{p}_{Z Y 1} \boldsymbol{r}_{Y 1 Z}$, (6) the path equation through $\mathrm{Y}_{2}$, namely $\mathrm{P}_{6}: \boldsymbol{r r}_{X 2 Z}=\boldsymbol{p}_{Y 2 X 2} \boldsymbol{r}_{X 2 Y 2}+$ $p_{Z Y 2} r_{Y 2 Z}$.

The path equation from $\mathrm{X}_{1}$ to $\mathrm{Z}$ through $\mathrm{Y}_{1}$, namely (1) $\mathrm{P}_{7}: \quad r_{X 1 Z}=p_{Y 1 X 1} r_{X 1 Y 1}+p_{Y 2 Y 1} r_{Y 1 Y 2}+p_{Z Y 1} r_{Y 1 Z}$, and the path equation from $\mathrm{X}_{1}$ to $\mathrm{Z}$ through $\mathrm{Y}_{2}$, namely $\mathrm{P}_{8}$ : $r_{X 1 Z}=p_{Y 2 X 1} r_{X 1 Y 2}+p_{Y 2 Y 1} r_{Y 1 Y 2}+p_{Z Y 2} r_{Y 2 Z}$. The path equation from $\mathrm{X}_{2}$ to $\mathrm{Z}$ through $\mathrm{Y}_{1}$, namely $\mathrm{P}_{9}$ : $r_{X 2 Z}=p_{Y 1 X 2} r_{X 2 Y 1}+p_{Y 2 Y 1} r_{Y 1 Y 2}+p_{Z Y 1} r_{Y 1 Z}$, and the path equation through $\mathrm{Y}_{2}, \mathrm{P}_{10}, \boldsymbol{r}_{X 2 Z}=\boldsymbol{p}_{Y 2 X 2} \boldsymbol{r}_{X 2 Y 2}+$ $p_{Y 2 Y 1} r_{Y 1 Y 2}+p_{Z Y 2} r_{Y 2 Z}$

Based on data analysis using SPSS version 21 , the standard coefficient $(\beta)$ is obtained from exogenous to endogenous variables, as in Table 6 below.

Table 6. Matrix of Standard Coefficients

\begin{tabular}{|c|c|c|c|c|c|}
\hline Variable & $\mathrm{X}_{1}$ & $\mathrm{X}_{2}$ & $\mathrm{Y}_{1}$ & $\mathrm{Y}_{2}$ & $\mathrm{Z}$ \\
\hline $\mathrm{X}_{1}$ & 1 & 0.974 & 0.334 & 0.314 & 0.362 \\
\hline $\mathrm{X}_{2}$ & 0.974 & 1 & 0.348 & 0.304 & 0.343 \\
\hline $\mathrm{Y}_{1}$ & 0.334 & 0.348 & 1 & 0.427 & 0.399 \\
\hline $\mathrm{Y}_{2}$ & 0.314 & 0.304 & 0.427 & 1 & 0.303 \\
\hline $\mathrm{Z}$ & 0.362 & 0.343 & 0.399 & 0.303 & 1 \\
\hline
\end{tabular}

The results of solving the path equation above using the data in Table 5 and Table 6 , obtained the path coefficients and impacts, as in Table 7 below.

Table 7. Path Coefficients and Impacts

\begin{tabular}{|c|c|c|}
\hline Path & $\begin{array}{c}\text { Path } \\
\text { Coefficients }\end{array}$ & Impacts \\
\hline $\mathrm{P}_{1}:$ Path $\mathrm{X}_{1}$ to $\mathrm{Z}$ & 0.576 & Medium \\
\hline $\mathrm{P}_{2}$ : Path $\mathrm{X}_{1}$ to $\mathrm{Y}_{1}$ to $\mathrm{Z}$ & 0.482 & Medium \\
\hline $\mathrm{P}_{3}$ : Path $\mathrm{X}_{1}$ to $\mathrm{Y}_{2}$ to $\mathrm{Z}$ & 0.387 & Low \\
\hline $\mathrm{P}_{4}:$ Path $\mathrm{X}_{2}$ to $\mathrm{Z}$ & 0.560 & Medium \\
\hline $\mathrm{P}_{5}: \mathrm{Path}_{2}$ to $\mathrm{Y}_{1}$ to $\mathrm{Z}$ & 0.489 & Medium \\
\hline $\mathrm{P}_{6}:$ Path $\mathrm{X}_{2}$ to $\mathrm{Y}_{2}$ to $\mathrm{Z}$ & 0.377 & Low \\
\hline $\mathrm{P}_{7}:$ Path $\mathrm{X}_{1}$ to $\mathrm{Y}_{1}$ and $\mathrm{Y}_{2}$ to $\mathrm{Z}$ & 0.768 & High \\
\hline $\mathrm{P}_{8}:$ Path $\mathrm{X}_{1}$ to $\mathrm{Y}_{2}$ and $\mathrm{Y}_{1}$ to $\mathrm{Z}$ & 0.674 & High \\
\hline $\mathrm{P}_{9}:$ Path $\mathrm{X}_{2}$ to $\mathrm{Y}_{1}$ and $\mathrm{Y}_{2}$ to $\mathrm{Z}$ & 0.776 & High \\
\hline $\mathrm{P}_{10}$ : Path $\mathrm{X}_{2}$ to $\mathrm{Y}_{2}$ and $\mathrm{Y}_{1}$ to $\mathrm{Z}$ & 0.664 & High \\
\hline
\end{tabular}

Based on Table 7, it can be stated that the path consists of two things, namely direct and correlational path. The path coefficient for $\mathrm{P}_{1}, \boldsymbol{r}_{\boldsymbol{X} \mathbf{}}=\mathbf{0 . 5 7 6}$, where variable $\mathrm{X}_{1}$ has a medium impact on variable $Z$. That means, teacher performance in building mathematical resilience has a medium impact on student learning outcomes. Path coefficient for $\mathrm{P}_{2}, \boldsymbol{r}_{X \mathbf{X 1 Z}}=\mathbf{0 . 4 8 2}$, where the path of the variables $X_{1}$ through $Y_{1}$ has a medium impact on variable $Z$. That means, the teacher's performance in building 
mathematical resilience has a medium impact on students' mathematical resilience to influence student learning outcomes. The path coefficient for $\mathrm{P}_{3}, \boldsymbol{r}_{X Z}=\mathbf{0 . 3 8 7}$, where the path of the variable $X_{1}$ through $Y_{2}$ has a low impact on variable $Z$. That means, teacher performance in building mathematical resilience has a low impact on students' mathematical literacy abilities to influence student learning outcomes.

The path coefficient for $\mathrm{P}_{4}, \boldsymbol{r}_{X \mathbf{} Z}=\mathbf{0 . 5 6 0}$, where the path of variable $X_{2}$ has a medium impact on variable $Z$. That means, teacher performance in building mathematical literacy has a medium impact on student learning outcomes. The path coefficient for $\mathrm{P}_{5}$, $\boldsymbol{r}_{X 2 Z}=\mathbf{0 . 4 8 9}$, where the path of the variable $X_{2}$ through $\mathrm{Y}_{1}$ has a medium impact on the $\mathrm{Z}$ variable. That means, the teacher's performance in building mathematical literacy has a medium impact on students' mathematical resilience to influence student learning outcomes. The path coefficient for $\mathrm{P}_{6}, \boldsymbol{r}_{X 2 Z}=\mathbf{0 . 3 7 7}$, where the path of the variable $\mathrm{X}_{2}$ has a low impact on $\mathrm{Y}_{2}$ to influence the $\mathrm{Z}$ variable. That is, the teacher's performance in building mathematical literacy has a low impact on students' mathematical literacy abilities to influence student learning outcomes.

The path coefficients for $\mathrm{P}_{7}, \boldsymbol{r}_{X 1 Z}=\mathbf{0 . 7 6 8}$, where the path of the variable $X_{1}$ through $Y_{1}$ which is influenced by $\mathrm{Y}_{2}$ has a high impact on the $\mathrm{Z}$ variable. That means, teacher performance in building mathematical resilience has a high impact on students' mathematical resilience which is influenced by students' mathematical literacy to influence student learning outcomes. The path coefficient for $\mathrm{P}_{8}, \boldsymbol{r}_{\boldsymbol{X 1 Z}}=\mathbf{0 . 6 7 4}$, where the path of the variable $\mathrm{X}_{1}$ through $Y_{2}$ which is influenced by the $Y_{1}$ variable has a high impact on the $\mathrm{Z}$ variable. This means that the teacher's performance in building mathematical resilience has a high impact on students' mathematical literacy skills which is influenced by students' mathematical resilience to influence student learning outcomes. The path coefficient for $\mathrm{P}_{9}, \boldsymbol{r}_{X 1 Z}=\mathbf{0 . 7 7 6}$, where the path of the variable $X_{2}$ through $Y_{1}$ which is influenced by $Y_{2}$ has a high impact on the $Z$ variable. That means, the teacher's performance in building mathematical literacy has a high impact on mathematical resilience which is influenced by students' mathematical literacy abilities to influence student learning outcomes. The path coefficient for $\mathrm{P}_{10}$, $\boldsymbol{r}_{X 2 Z}=\mathbf{0 . 6 6 4}$, where the path of the variable $X_{2}$ through $\mathrm{Y}_{2}$ which is influenced by $\mathrm{Y}_{1}$ has a high impact on the $\mathrm{Z}$ variable. That means, the teacher's performance in building mathematical literacy has a high impact on students' mathematical literacy abilities which is influenced by the mathematical resilience of students to influence student learning outcomes.

\section{Discussion}

The results of descriptive analysis show that the teacher's performance in developing mathematical resilience and literacy is in the medium category. This result is in accordance with a study by Muntazhimah \& Ulfah [31] which states that the mathematical resilience of mathematics teachers is low. Furthermore, the results of this study indicate that students' mathematical resilience, students' mathematical literacy abilities and student learning outcomes are in the medium category. This ability is in line with studies which show that students in Indonesia have low mathematical literacy skills [32-34], the mathematical literacy skills of prospective teachers are categorized as medium [35]. Meanwhile, moderate category student learning outcomes can be caused by the performance of teachers who are in the medium category, because teacher performance affects student learning outcomes [36], and teacher performance in the learning process still experiences several obstacles that affect student learning outcomes [37-38]

The results of inferential analysis partially show that teacher performance in building resilience and mathematical literacy has a moderate impact on student learning outcomes. The teacher's performance in building mathematical resilience has a moderate impact on students 'mathematical resilience, and has a low impact on students' mathematical literacy abilities to influence student learning outcomes. This is in line with Zanthy's study [39] showing that the effect of mathematical resilience on students' abilities is in the medium category, and resilience is related to mathematical literacy [40].

Furthermore, the teacher's performance in building mathematical literacy has a moderate impact on students' mathematical resilience, and has a low impact on students' mathematical literacy abilities to influence student learning outcomes. The impact and relationship is in line with the statement that there is a relationship between mathematical literacy skills and students' mathematics learning outcomes [41]. There is an influence of students' mathematical literacy abilities on their learning achievement [42], and mathematical literacy abilities are one of the factors that affect students' mathematics achievement [43].

Simultaneously, teacher performance in building mathematical resilience has a high impact on students' mathematical resilience which is influenced by students' mathematical literacy abilities to influence student learning outcomes. The teacher's performance in building mathematical resilience has a high impact on students' mathematical literacy abilities which is influenced by students' mathematical resilience to influence student learning outcomes. The existence of these impacts and effects is consistent with the results of several studies which show that mathematical resilience is related to learning outcomes [44-45]. There is an effect of mathematical resilience on student learning outcomes in mathematics [23], [37], [46].

Furthermore, the teacher's performance in building mathematical literacy has a high impact on the 
mathematical resilience of students which is influenced by students' mathematical literacy abilities to influence student learning outcomes. The teacher's performance in building mathematical literacy has a high impact on students' mathematical literacy abilities which is influenced by students' mathematical resilience to influence student learning outcomes in mathematics. This is in accordance with what was stated by Susanti \& Syam [6] that the ability of teachers to carry out the learning process can improve students' mathematical resilience and literacy.

\section{Conclusions}

Resilience and mathematical literacy skills are needed to achieve good learning outcomes. This can be obtained if the teacher's performance can build resilience and mathematical literacy properly. Therefore, a study is needed to analyze it. The results of the study with descriptive analysis conclude a number of things, namely (1) the teacher's performance in building mathematical resilience and literacy is in the medium category, (2) students' mathematical resilience, students' mathematical literacy abilities and student learning outcomes are in the medium category. The results of inferential analysis partially show that the teacher's performance in building mathematical resilience, namely (3) has a moderate impact on students' mathematical resilience to influence student learning outcomes, and (4) has a low impact on students' mathematical literacy abilities to influence student learning outcomes. The teacher's performance in building mathematical literacy, namely (5) has a moderate impact on mathematical resilience to influence student learning outcomes, and (6) has a low impact on mathematical literacy skills to influence student learning outcomes in mathematics.

Simultaneously, the teacher's performance in building mathematical resilience, namely (7) has a high impact on students 'mathematical resilience which is influenced by students' mathematical literacy abilities to influence student learning outcomes, and (8) has a high impact on students' mathematical literacy abilities which is influenced by students' mathematical resilience to influence student learning outcomes. Furthermore, the teacher's performance in building mathematical literacy, namely (9) has a high impact on students' mathematical resilience which is influenced by students' mathematical literacy abilities to influence student learning outcomes, and (10) has a high impact on students' mathematical literacy abilities which is influenced by students' mathematical resilience to influence student learning outcomes in mathematics. Thus it can be stated that the performance of teachers in building resilience and mathematical literacy has an impact on student learning outcomes.
Thus it can be stated that the performance of teachers in building resilience and mathematical literacy has an impact on student learning outcomes. Based on these findings, it is necessary to make various efforts to improve students' mathematical resilience and literacy. Further studies for this can be carried out several studies, such as teacher knowledge and other factors that can affect students' mathematical literacy and resilience, so that student learning outcomes become better.

\section{REFERENCES}

[1] OECD, "PISA 2018, Results Combined Executive Summaries". Paris: PISA, OECD Publishing, Volume I, II \& III, pp. 1-63, 2019. https://www.oecd.org/pisa/Combined_E xecutive-Summa-ries_PISA_2018.pdf

[2] OECD, "PISA 2012, Assessment and Analytical Framework: Mathematics, Reading, Science, Problem Solving and Financial Literacy". Paris: PISA, OECD Publishing., pp. 1-60, 2013. http://dx.doi.org/ 10.1787/9789264190511

[3] Bobby Ojose, "Mathematics Literacy: Are We Able to Put the Mathematics We Learn Into Everyday Use?". Journal of Mathematics Education, Vol. 4, No.1, pp. 89-100, 2011. file://C:/Users/acer/Downloads/mathematics-literacy-are-w e-able-education-for-all.pdf

[4] Kaye Stecey., Ross Tuner, "Assessing Mathematical Literacy: The PISA Experience”. Australia: Springer, 2015.

[5] Puji Astuti, "Mathematical Literacy Skills and High-Level Thinking Skills". PRISMA, Prosiding Seminar Nasional Matematika, I, pp. 263-266, 2018. https://journal.unnes.ac.i d/sju/index.php/prisma/

[6] Elsa Susanti., Salmaini Safitri Syam, "The Role of Teachers to Improve Indonesian Students' Mathematical Literacy Ability". Conference: Seminar Nasional Matematika dan Pendidikan Matematika UNY, pp. 30-35, 2017. file://C:/Users/acer/Downloads/Peran\%20Guru\%20dalam $\% 20$ Meningkatkan\%20Kemampuan\%20Literasi\%20Mate matika

[7] Kusaeri., Ekky Dea Henwi Cahyan, “Attitudes, Expectations, and Students' Perceptions of Mathematics and Its Implications for Self-Regulation Abilities". Jurnal Pengajaran MIPA, Vol. 2, No.2, pp. 114-121, 2016. DOI: 10.18269/jpmipa.v21i2.818

[8] M. Syawahid., Susilahudin Putrawangsa, "Junior High School Students' Mathematical Literacy Skills in Terms of Learning Styles". Jurnal Tardis Matematika, Vol.10, No. 2, pp. 222-240, 2017. DOI: http://dx.doi.org/10.20414 /betajtm.v10i2.121

[9] Abdul Gani, "The Influence of Learning Models and Perceptions of Mathematics on the Interest and Learning Outcomes of State SMP Students in Salomekko District, Bode Regency". Jurnal Daya Matematis, Vol. 2, No.3, pp.337-343, 2016. https://ojs.unm.ac.id/index.php/JDM/arti cle/view/1700

[10] Bambang Sri Anggoro, “Analysis of Junior High School 
Students' Perceptions of Mathematics Learning in Terms of Gender Differences and Mathematical Creative Thinking Dispositions". Al-Jabar: Jurnal Pendidikan Matematika, Vol. 7, No. 2, pp. 153-166, 2016. https://core.ac.uk/download/pd f/267855245.pdf

[11] Johnson Wilder., Sue., Lee Clare, "Developing Mathematical Resilience", A Paper Presented at the BERA Conference $1^{\text {st }}-4^{\text {th }}$ September 2010, 2010.http://www.ber aconference.co.uk/2010/

[12] Carol S. Dweck, "Self-Theories. Their Role in Motivation, Personality, and Development". New York: Psychology Press. 2013. DOI: https://doi.org/10.4324/978131578304 8

[13] Agusmanto J. B. Hutauruk., Nanang Priatna. "Mathematical Resilience of mathematics education students". Journal of Physics: Conf. Series, 895, 1-6, 2017.doi :10.1088/1742-65 96/ 895/1/012067

[14] Hersh C. Waxman., Jon P. Gray., Yolanda N. Padron. "Review of Research on Educational Resilience". Santa Cruz: Center for Research on Education Diversity and Excellence, University of California, 1-19, 2003. https://escholarship.org/content/qt7x695885/qt7x695885 n oSplash_aaf464d4631ff846687c455222cc5532.pdf?t=krn9k o

[15] Mihir K. Mallick., Simranjit Kaur, "Academic Resillience Among Senior Secondary School Students: Influence of Learning Environment". Rupkatha Journal on Interdisciplinary Studies in Humanities, Special Issue, VIII (2), 20-27, 2016. http://rupkatha.com/V8/n2/03_Academic_ Resilience.pdf

[16] Bonnie Benard, "Resiliency: What We Have Learned". San Francisco, CA: WestEd Regional Educational Laboratory, 2004.

[17] Asep Ikin Sugandi, "Increasing Creative Thinking Ability and Mathematical Resilience of Junior High School Students Through a Generative Approach". Jurnal Perspektif Pendidikan, Vol. 11, No. 2, pp.49-56, 2017. http://download. Garuda .ristekdikti.go.id/article.php?rticle $=1069724 \& v a l=1$ 6055\& title

[18] Simon Cassidy, "Resilience Building Students: The Role of Academic Self-Efficacy". ORIGINALRESEARCH, Vol. 6, Article 1781, pp.1-14, 2015. Doi: 10.3389/fpsyg.2015.0178 1.

[19] Hanna Onyi Yusuf., Abdullahi Aliyu Dada, "Impact of Teachers' Qualification and Experience on the Performance of Students' in Colleges of Education in Kaduna State, Nigeria". The Online Journal of Quality in Higher Education, Vol.3, No. 2, pp, 52-61, 2016. file://C:/Users/acer/Downlo ads/IMPACT\%20OF\%20TEACHERS\%20QUALIFICATI ON\%20AND\%20EXPERIENCE\%20NIGERIA.pdf

[20] Arif M. Sardiman, "Interaksi dan Motivasi Belajar Mengajar”. Jakarta: Penerbit Raja Grafindo Persada. 2011

[21] Mohamed Z. G. Al-Agili, Mustafa Bin Mamat, Lazim Abdullah, Hamdan Abdul Maad, "The Factors Influence Students' Achievement in Mathematics: A case for Libyan's Students". World Applied Sciences Journal, Vol. 17, No. 9, pp.1224-1230. 2012. file:///C:/Users/acer/Downloads/The\% 20 Factors\%20Influence\%20Students\%20Achievement
[22] Justice Enu., Osei K. Agyman, Daniel Nkum, "Factors Influencing Students Mathematics Performance in Some Selected Colleges of Education in Ghana". International Journal of Education Learning and Development, Vol. 3, No. 3, pp. 68-74, 2015. http://www.eajournals.org

[23] Stefani Ayuning Iman., Dani Firmansyah, "The Effect of Mathematical Resilience Ability on Mathematics Learning Outcomes". Prosiding Seminar Nasional Matematika dan Pendidikan Matematika Sesiomadika, Desember 2019, Vol.2, No. 2, pp. 356-360, 2019. https://jounal.unsika.ac.id/ index.php/sesiomadika/article/view/2601

[24] Wendy Conklin, "Higher Order Thinking Skills to Develop $21^{\text {st }}$ Century Learners". Huntington: Shell Education Publishing, Inc. 2011.

[25] Hodiyanto, "The Relationship Between Mathematical Problem Solving Ability and Mathematical Connection Ability with Student Learning Achievement". Jurnal Pendidikan Informatika dan Sains, Vol. 6, No. 2, pp. 208-218. 2017. file:///C:/Users/acer/Downloads/645-2557-1 -PB.pdf

[26] Elizabeth Bondy., Dorene D. Ross., Caitlin Gallingane., Elyse Hambacher, "Creating Environment of Success and Resilience: Culturally Responsive Classroom Management and More. Urban Education, Vol. 4, No. 2, pp. 326-348, 2007. DOI:10.1177/ 0042085907303406

[27] Suharsimi Arikunto, "Prosedur Penelitian". Jakarta: Rineka Cipta. 2012.

[28] C. G. Sevilla, J. A. Ochave, T. G. Punsalan, B. P. Regala, G. G. Uriarte, "Research Methods". Quezon City: Rex Printing Company, 2007.

[29] Mary J. Allen., Wendy M. Yen, "Introduction to Measurement Theory". Monterey: Brooks Cole, 1979.

[30] Sugiyono, "Statistika untuk Penelitian". Bandung: Alfabeta Publishing Company, 2011.

[31] Muntazhimah., Syafika Ulfah, "Mathematics Resilience of Pre-Service Mathematics Teacher". International Jounal of Scientific \& Technology Resarch, Vol. 9, No. 1, pp. 1442-1445, 2020. file:///C:/Users/acer/Downloads/IJSTRM athematics-Resilience-Of-Pre-service-Mathematics-Teacher .pdf

[32] Nur Indah., Sitti Mania., Nursalam, 'Improving Students' Mathematical Literacy Skills Through the Application of Problem-Based Learning Models in Class VII SMP Negeri 5 Palangkaraya, Gowa Regency". Jurnal Matematika dan Pembelajaran (MaPan), Vo. 4, No. 2, pp. 200-210, 2016. https://www.researchgate.net/profile/Nursalam_Nursalam2/ publication $/ 324593928$

[33] Rifai., Dhoriva Urwatul Wutsqa, "Mathematical Literacy Ability of State SMP Students in Bantul Regency". Jurnal Pendidikan Matematika dan Sains, Vol. 4, No. 2, pp. 152-162, 2017. file:///C:/Users/acer/Downloads/15747-421 08-1-PB.pdf

[34] Rosalina Hera Novita Sari., Ariyadi Wijaya, "Mathematical Literacy of Senior High School Students in Yogyakarta". Jurnal Riset Pendidikan Matematika, Vol. 4, No. 1, pp.100-107, 2017. doi:http://dx.doi.org/10.21831/jrpm.v4i1 .10649 
[35] Yani Setiani., Isna Rafianti, "Effect of Visual-Spatial Intelligence Level on Quantitative Literacy of Mathematics Teacher Ccandidates". Jurnal Matematika Kreatif-Inovatif, Vol. 9, No.1, pp. 38-46, 2018. https://journal.unnes.ac.id/nj u/index.php/kreano/issue/view/921

[36] Sitti Nur Suraya Ishak., Suyatno. "Teacher Performance, Parent's Role, and Student Learning Outcomes in Muhammadiyah Junior High School". Universal Journal of Educational Research, Vol. 8, No. 2, pp. 529-539, 2020. DOI: 10.13189/ujer.2020.080224

[37] Mu'alimin., Sultan Syahrir., Meriyati., Fauzan., Muhammad Thoyib, "Teachers' Performance in Madrasa Aliyah Central Lampung Regency". Universal Journal of Educational Research, Vo.8, No.4, pp. 1341-1344, 2020. DOI: 10.13189/ ujer.2020.08042

[38] Hardi Tambunan, "Kinerja Guru Matematika SMP dalam Membangun Minat dan Motivasi Belajar Siswa". Jurnal Riset Pendidikan Matematika, Vol. 7, No. 1, pp. 108-117, 2020. doi: https://doi.org/10.21831/jrpm.v7i1.19384

[39] Luvy Sylviana Zanthy, "Contribution of Mathematical Resilience to Student's Academic Ability in Mathematical Statistics Course". Jurnal "Mosharafa", Vol. 7, No. 1, pp. 85-93, 2018.https://media.neliti.com/media/publications/22 6618-kontribusi-resiliensi-matematis-terhadap-cfd4a3d6.pd $\mathrm{f}$

[40] Ice Afriyanti., Mulyono., Tri Sri Noor Asih, "Mathematical Literacy Skills Reviewed from Mathematical Resilience in the Learning of Discovery Learning Assisted by Schoology". Journal of Mathematics Education Research, Vol.7, No. 1, pp. 71-78, 2018. http://journal.unnes.ac.id/sju/index.php/uj mer

[41] Made Widya Suryaprani., I Nengah Suparta., I Gusti Putu Suharta, "Relationship Between Gender, Mathematical
Literacy, and Mathematical Disposition on Mathematics Learning Achievement of Students in Public High Schools in Denpasar". Prosiding Seminar Nasional MIPA 2016, pp. 39-46, 2016. file:///C:/Users/acer/Downloads/adoc.pub pro siding-seminar-nasional-mipa-2016.pdf

[42] Indah Puji Handayani, "The Influence of the Literacy Program on Student Achievement in SMA Negeri 21 Surabaya”. Inspirasi Manajemen Pendidikan, Vol. 6, No. 6, pp, 1-8, 2018. https://jurnalmahasiswa.unesa.ac.id/index.ph $\mathrm{p} /$ inspirasi-manajemen-pendidikan/issue/archive

[43] Rogers Pakpahan, "Faktors Affecting Literacy Mathematics of Indonesian Student in PISA 2012". Jurnal Pendidikan dan Kebudayaan. Vol.1, No.3, pp. 331-347, 2016. https://media. neliti.com/media/publications/119607-faktorfaktor-yang-me mengaruhi-capaian-1-403f3c78.pdf

[44] Sri Maharani., Martin Bernard, "Analysis of the Relationship of Mathematical Resilience to Students' Problem Solving Abilities in Circle Material”. Jurnal Pembelajaran Matematika Inovatif, Vol. 1, No. 5, pp. 819-826, 2018. DOI: 10.22460/jpmi.v1i5. p819-826.

[45] Aurora León Hernández., Sergio González Escobar., Norma Ivonne González Arratia López Fuentes., Blanca E. Barcelata Eguiarte, "Stress, Self-Efficacy, Academic Achievement and Resilience in Emerging Adults". Electronic Journal of Research in Educational Psychology, 17 (1), 129-148, 2019. http://repositorio.ual.es/bitstream/ha ndle/10835/7605/2226-7060-1-PB eng.pdf?isAllowed=y\& sequence $=2$

[46] Kartika Sari Asih., Isnarto., Sukestiyarno., Wardono., "Mathematical Resilience in Discovery Learning in an Effort to Improve Mathematics Communication". PRISMA 2, Prosiding Seminar Nasional Matematika 2019, pp.862-868, 2019. https://journal.unnes.ac.id/sju/index.php/ prisma/issue/view/1445 